\title{
The formation of the Warrior's Status based on a review of the Hojyo-Ryu Heiho Series
}

\author{
Kentaro TAI ${ }^{*}$, Tatsuo YAGI ${ }^{2}$, Masaki FUMOTO ${ }^{3}$, Kohki KINIWA ${ }^{4}$, \& Hiroyuki IMAMURA ${ }^{1}$ \\ ${ }^{1}$ Nagasaki International University (Japan) \\ 2 Seiwa University (Japan) \\ ${ }^{3}$ Tokyo International University (Japan) \\ ${ }^{4}$ Hiroshima University Graduate School of Integrated Arts and Sciences (Japan)
}

\section{5th IMACSSS World Scientific Congress Abstracts, Rio Maior (Portugal), October 6-8} Section: Historical, sociological and philosophical issues of MA\&CS Type: Poster communication

\section{Introduction}

Various Japanese budo have evolved into their modern form since the Meiji period (1868-1912). The brutal early modern martial arts have been transformed into a combination of skills acquisition and the cultivation of personal moralistic values. Several recent studies have indicated that combat techniques in the early modern period (1603-1868) were not necessarily focused mainly on killing or inflicting injury. This is perhaps because of the clear break in this period from the violence and upheaval in the medieval world. That is, that suggested that combat techniques in the early modern period have been given the new function. Considering the educational essence of Japanese martial arts as a combative sport, and questioning the established wisdom surrounding this topic until now, this poses an important problem. We cannot fully understand contemporary budo without a clear grasp of the meaning of " $b u$ " ("martial") in the early modern times and how it connects to Japanese martial arts in the late modern era.

\section{Methodology}

We will discuss the establishment of the concept of Japanese budo and its origins as a physical art in the early modern times, which is when their core elements are thought to have arisen. This study identifies the formation of the warrior's status through physical techniques in the early modern period.

\section{Results and discussion}

Throughout the medieval period, the Bushi class was the sole authority on combat techniques. However, once the shogunate system stabilised in the early-modern period, the bureaucratic scholar-official class supported by Confucian scholars, particularly the Hayashi clan of Confucian scholars, was held up as the new Bushi ideal. The Bushi philosophy based on the Confucian scholarofficial system was, in some respects, incompatible with the demands of the shogunate which encouraged the Bushi to see themselves as a warrior class. Ujinaga Hojyo (1609-1670), the founder of the Hojyo ryu Heiho, was appointed as instructor of military strategy to help overcome this incompatibility. However, Ujinaga Hojyo was not a mere military strategist; in the course of his important work as an inspector general for the shogunate, he was also able to circumscribe the characteristics of the ideal samurai from a more global perspective.

Ujinaga Hojyo had studied military strategy of the Koshu ryu, and later found his own school. Military strategy texts of the Koshu ryu indicated the techniques involving the use of magic that had 
been employed to a considerable extent in medieval warfare. The Hojyo ryu texts deliberately rejected such techniques. The scope of the newly built system of techniques was expanded beyond the traditional battlefield, and its applicability in the realm of governance at peacetime was strongly emphasized. Moreover, the texts sought to clarify the position of the samurai within society by defining them as government officials whose role was to suppress banditry.

Ideas concerning military strategy thus moved from the battlefield to the spheres of national law and order, while the concept of the Bushi shifted from warrior to official. This role was likened to that of the Bushi captains and foremen who commanded foot soldiers in battle and ensured strict adherence to martial law by cracking down on deserters. Soko Yamaga (1622-1685), who had studied military strategy from Ujinaga Hoyjo, would later articulate an ethical viewpoint for the Bushi known as the 'shido' (Bushi code). Questions of what exactly shi was meant to do, as distinct from peasants, artisans, and merchants, had already been discussed in early-modern Japanese society within the military strategy texts of the Hoyjo ryu, prior to Soko Yamaga.

\section{Conclusion}

While the Koshu ryu of strategy established a Bushi code of conduct based entirely on their role as warriors, the texts of the Hojyo ryu can be seen as part of the process in which the role of the samurai became focussed around peacetime officialdom, comparable to that of the Confucian scholar-official. Nonetheless, the persistent need to re-affirm a Bushi raison d'etre in medieval techniques of military strategy highlights the effort made to situate this class of warriors, specialized in martial arts and the art of warfare, within the wider society.

\section{References}

Ishioka, H. (1972). History of Heiho in Japan. Yuzankaku, Tokyo. Arima, S. \& Ishioka, H. (1967). Nihon Heiho Serirs 3 Hojyo-ryu Heiho. Tokyo: Jimbutsu Orai. Maeda, T. (1996). Confucianism and Heigaku in Early modern times Japan. Tokyo: Perikan Books.

Key words: Budo; martial arts; Hojyo-ryu Heiho; bushi; bugei. 